\title{
The Community Asset Transfer of Leisure Facilities in the UK: A Review and Research Agenda
}

\author{
Geoff Nichols $^{1} \cdot$ Lindsay Findlay-King $^{2}$ (I) $\cdot$ Deborah Forbes $^{3}$
}

Published online: 3 September 2020

(C) The Author(s) 2020

\begin{abstract}
This paper reviews recent work on community asset transfers (CAT): a transfer of management of facilities from the public sector to the third sector, largely led by volunteers. The emergence of CATs is placed in the context of the development of community organisations and their relation to the state. Transfer has been stimulated by cuts in local government budgets since 2010. The review focusses on leisure facilities because these are non-statutory and so more vulnerable to cuts in public expenditure. The experience of CATs is reviewed, including: the motivations of local government and volunteers; the transfer process and management of CATs post-transfer; and the market position of facility types. The methodological approaches and theoretical frameworks used in research are contrasted; in particular, how these have balanced agency and structure in analysing a contested neoliberalist discourse. The practicalities of research in this area are considered before concluding with research questions.
\end{abstract}

Keywords Community asset transfer · Voluntary association - Leisure and culture

Lindsay Findlay-King

Lindsay.Findlay-King@northumbria.ac.uk

Geoff Nichols

g.nichols@sheffield.ac.uk

Deborah Forbes

deborah.forbes@newcastle.ac.uk

1 University of Sheffield, Sheffield, UK

2 Department of Sport, Exercise and Rehabilitation, Northumbria University, Newcastle upon Tyne NE1 8ST, UK

3 University of Newcastle, Newcastle upon Tyne, UK

\section{Introduction}

This paper provides a comprehensive literature review of research into community asset transfer (CAT) of leisure and cultural facilities since 2010, leading to research questions. Community asset transfers are community-based organisations (Aiken et al. 2011) which have emerged in response to cuts in public expenditure since 2010. They involve a transfer from local government management to management by volunteers. Thus researching CATs contributes to a debate about where the boundary should lie between statutory responsibility and voluntary initiative (Lindsey et al. 2018). Our focus is on the UK; however, implications will be relevant to other countries where neoliberalism has influenced a reduction in the role of the state. Within the UK, differences between England, Northern Ireland and Scotland are noted although they are all influenced by broadly similar political and economic circumstances.

The paper has eight sections. We firstly define CAT, as distinct from co-production and social enterprises and as a particular type of community based organisation. Secondly, we describe the literature review strategy. The academic review was complemented by a structured discussion of policy makers that provided leads to recent survey work and other 'grey literature'. These sources inform the following sections of the paper. Thirdly, we justify the focus on leisure facilities; such as sports centres, libraries, museums and heritage centres. We consider the different positions of these facilities within a 'leisure market' because government policy from 2010 has been to regard volunteer led organizations as one competitor in a market for the delivery of public services (Aiken and Taylor 2019; Lindsey et al. 2018). The market positions of facilities influence the decision to transfer them to a local 
volunteer led group and the ability of the CAT to achieve economic sustainability. Fourthly, the review material is used to describe the political and economic context. This helps understand influences on discourses describing volunteering, public leisure services, and government policy. A fifth section describes the experience of CAT, including: motivations of local government and volunteers, managing transfer, and changes in facility services and delivery.

We then review the theoretical frameworks and methodologies used in CAT research; including the social constructions of CATs and contested discourses. A seventh section reviews the practicalities of research into CATs; including sampling, case studies and negotiating access. Lastly, we propose a research agenda.

\section{Defining Community Asset Transfer}

The Department of Communities and Local Government (DCLG, now Ministry of Housing, Communities and Local Government (MHCLG) define CAT as the transfer of management and/or ownership of public land and buildings from its owner (usually a local authority) to a community organisation for less than market value-to achieve a local social, economic or environmental benefit (Locality 2018b). We have taken a 'community organisation' to be one in which volunteers take a major role in governance or delivery; as illustrated by the review material. The definition includes land or buildings, but not services.

Distinguishing a CAT from a social enterprise needs to consider that both are socially constructed concepts. For Teasdale 'social enterprise is a contested concept which encompasses a large range of organisations evolving from earlier forms of non-profit, co-operative and mainstream business. ... In particular, social enterprise has been associated with a neo-liberal discourse promoting the power of business to achieve fundamental social change' (2012, p. 100). Teasdale traces the dominant discourse; 1990-2010; from 'co-operative', to 'community enterprise', to 'social business', to 'earned income for nonprofits'. If one accepts Teasdale's analysis, it places CATs in a succession of organisational forms; the social construction of which is dominated by a neoliberal discourse. We will return to this point when discussing alternative theoretical frameworks. CAT is not co-production, although different definitions of this all involve the public sector and the public working together (Bovaird and Loeffler 2012). In CATs, management has been transferred entirely to volunteers running them although local government may retain ownership of the building. They correspond to the first type of community-based organisation identified in Aiken et al's review (2011), termed 'Stewards'. These were small, mainly volunteer-run groups with a single, asset (usually a building) used largely for hiring out to local community groups and residents.

\section{Review Strategy}

The literature search; conducted in April 2020; used a range of strategies because community asset transfer is a new concept and it overlaps with a wide range of terms. Thus while the review was focussed on CAT of leisure facilities it included material on social enterprise and the changing relationship between the voluntary sector and the state, to place CAT in context.

A search through Scopus used the terms "community asset transfer" to find articles and reviews; limited to those published after 2007 when the Quirk Review (2007) represented a shift in policy favouring CAT. This produced 135 items in English. The search was widened to the term "asset transfer". The 1927 results were filtered for those, which were in, or referenced, the leading Third Sector journals. This strategy was complemented by a search for "asset transfer" in these journals directly; revealing eight further references. A further source was references in two recent PhD theses (Foxton 2018; Rex 2018a). The review was confined to work in the UK because of the political and economic context apart from a particularly relevant Australian paper (Griffiths et al. 2014).

Additional articles and theses were identified through cross references and the authors' previous research. As much recent research on CAT has been published in the form of reports we also consulted members of a review group of policy makers and practitioners, which met with the authors of this paper in February 2019. This group comprised representatives of Power to Change, Community Leisure UK, the Community Managed Libraries Peer Network, Arts Council England and a council library volunteer coordinator (1). Power to Change and Locality were able to provide access to a range of reports, which were not revealed using academic search engines. This meeting was used to elicit the research questions that were important to practitioners. These informed the questions we conclude this review with, although their main foundation is in the reviewed material.

\section{The Extent of Community Asset Transfer of Public Leisure Facilities and Their Market Position}

Leisure facilities; including sports centres, playing fields, museums, libraries and parks; provide a focus for our examination of the changing boundary between statutory responsibility and voluntary initiative because, apart from an ill- defined legal requirement to provide a library 
service, local authority provision is discretionary rather than statutory. The high point of leisure as a welfare right was in 1975 when the Labour Government's White Paper 'Sport and Recreation' gave access to recreation the status of a right as part of the fabric of the social services (Veal 2010). A change of government in 1979 led to the dominance of a neo-liberalist ideological position in which the flexibility of the market was seen as the ideal mechanism for providing for people's leisure demands. Thus, sport and leisure never quite attained the status of a right of citizenship, in contrast to health care and secondary education. The vulnerability of these services to cuts in local government budgets is confirmed by Gilbert's (2016) limited sample of CATs, showing that the four most likely facilities to be transferred in the last 5 years were community centres, public green spaces, sports facilities and libraries.

It is important to understand the different market positions of sport facilities, libraries, museums and heritage buildings because central government policy is to give voluntary organisations the opportunity to participate in markets (Lindsey et al. 2018, p. 37) and because the dominant discourse is to define them as a business (Teasdale 2012; Aiken and Taylor 2019). Overall, the different markets for assets is reflected in the balance between transfers to national organisations and those to CATs. For example, while there are many library CATs, there are few of sports facilities, because their profitability allows transfer to national providers.

The market for management of public sports facilities is dominated by a few large providers (Findlay-King et al. 2018a), operating at a national level, and taking large contracts of profitable facilities. The proportion of leisure centres and swimming pools managed by local authorities has declined from $25 \%$ in 2014 to $18 \%$ in 2018 , whilst the number of facilities operated by Trusts has increased by $22 \%$ in the same period (Mintel 2018). Thirty-five per cent of the UK's leisure centres and swimming pools are now managed by Trusts and as a group, they are the largest operator in the sector (Mintel 2018). A review of 232 local authorities' websites (Livsey 2015) showed that nine national operators - the majority operating as a form of Non-Profit Distributing Organisation-managed facilities in $44 \%$ of authorities. Of 161 contracts with local authorities, three operators held $61 \%$. A national market for managing sports facilities exists because they have become profitable without subsidy (Ramchandani et al. 2018). The existence of national providers makes it attractive for local authorities to transfer a large tranche of facilities to one experienced operator. For example, in 2016 Newcastle City council transferred three facilities to North Country Leisure, which is part of the GLL group, "with a sound track record of successfully managing similar facilities in the North East' (Newcastle Chronicle 2016). The council wanted to include a fourth pool in the package, which was losing $£ 260,000$ a year, but no bidder would submit an offer had this been included. These large leisure trusts are not CATs, as the 'community', represented by local volunteers, will not be involved in planning or delivery. They correspond to Aiken et al.'s (2011) category of 'entrepreneurs', larger organisations with a mix of assets for social and commercial purposes.

This market structure means that the recent CATs in sport are likely to be smaller, single facilities (FindlayKing et al. 2018a) which national operators do not want to take on. Estimating numbers is difficult (for reasons discussed below) but the most recent estimate of assets in community ownership (Archer et al. 2019) estimated that of the 6325 community assets in England, 11\% are related to sport, and $29 \%$ came into community ownership in the last ten years. Once transferred, CATs will still have to react to their market position (e.g. Fenwick and Gibbon 2016; Reid 2018).

The market for transferring libraries, in contrast, is dominated by CATs. Since April 2011, at least 576 libraries have been transferred to being run entirely by volunteers for some of the time (Public Libraries News 2019a). The lack of commercial interest is because it is not possible to manage them profitably. Libraries cannot charge for their main service, lending books. For example, Lewisham council were not able to consider a commercial bidder to run the five libraries it proposed to close (Forkert 2016). The only large trusts to have taken contracts for outsourced library provision are: Carillion, who are now bankrupt; Greenwich Leisure Limited, who run library services in Bromley, Greenwich, Dudley, Wandsworth and Lincolnshire; and Libraries Unlimited, who run Torbay and Devon library services (O'Bryan 2018). In these cases, the library service has been combined with other uses of the building.

For museums, a recent study showed a decline of $14 \%$ in the number of state run museums operating in the UK. Nine percent represent museums transferring to trust status (Larkin 2018). This is an inaccurate picture of CATs because the $14 \%$ includes national as well as local authority museums, and the 9 per cent includes both larger trusts (Derby Museums Trust, for example) and CATs. The transfer of museums is not as prevalent as libraries, although the Museums Association have observed 'an ongoing trend among local authority museums to transfer operations outside council control' (2017, p10). Some services have been contracted to large-scale non-profit trusts operating with paid staff (Vivacity in Peterborough, for example, which delivers a range of leisure services). This is different to museums taken on by small-scale newly formed community organisations in which volunteers complete the majority of work. Many museums are not 
transferred via CAT, as local authorities do not offer local groups this option. This makes it difficult to assess the potential organisations in the market for managing museums, as the opportunity to manage a transfer is not always made available (Rex 2018a). Museums have limited opportunities to generate revenues. The historic nature of the buildings and underinvestment contribute to high maintenance costs. In general, these tend to outweigh the income generated because of a public policy commitment to free access; the age and structure of buildings; and the need for specialised professional staff to preserve and display artefacts. As with libraries, museums may introduce new ways of generating income from visitors, but a complication is the need to conserve collections, which may be costly in terms of human resources and space.

The market for heritage assets include buildings, land, structures, monuments, sculptures, archaeological remains, historic sites, and also some museums. Little research has focused specifically on transfer of these assets. A study by the Heritage Lottery Fund indicated that the number of CATs for heritage facilities has increased (NLHF 2017) and 97 Lottery Fund grants had been made to CAT projects between 2011/12 and 2016/17, with a significant increase occurring after 2013-2014. Transfers of heritage assets are again limited by high maintenance costs, and the complexity of management (Schultz 2016).

Although we have included parks as leisure facilities the only example of transfer of these we have found is from a district council to a parish council in 2011 (Sellick 2014) so we are unable to make generalisations about the market for park management: this example aimed to break even financially by 2015 . We have not examined the market for village halls separately as there is limited research on these (e.g. Scott and Probert 2018) although they are an important community asset.

\section{The Political and Economic Context of CATs}

As does the market position, the political and economic context also helps understand the structure within which CATs are socially constructed. This section describes this context. We discuss the extent to which CAT and related concepts are socially constructed and contested in a further section.

In 2007 the Quirk review of community management and ownership of public assets viewed CAT as local empowerment proclaiming that: 'A new civic spirit sweeps through urban, suburban and rural communities alikegalvanising communities to harness their energies for the wider public good' $(2007$, p. 3). This reflected the Third Way politics of New Labour in which the third sector was drawn into public service provision to reduce public spending with the justification that this would increase community cohesion. The focus was on, 'the formation of social capital as a route towards solving social problems, social innovation and reshaping the relationship between citizen and state' (Lindsey et al. 2018, p. 27). Quirk conceptualised the state and society as mutually reinforcing. The coalition government of 2010-2015 took the opposite view. The 'Big Society' concept assumed that removing investment from the state would engender more voluntary activity in society. The 2011 Localism Act formalised this by giving community groups a right to bid to take over community assets, and to challenge the local authority to take over public services. However, formal volunteering rates have been static since 1979 and informal volunteering reduced during the post-2008 recessionary period (Lindsey et al. 2018, p. 70) so reduced state spending did not succeed in promoting an expansion in volunteering.

It is impossible to disentangle the Big Society policy from the main driving force for CATs; the reduction in budgets for local authorities. Thus, since 2010, making savings '.. has been the overwhelming imperative' of local government (O'Leary et al 2011, p. 30). Between 2010 and 2015, the average cut in local authority budget across England was $£ 130.06$ per person. The 10 per cent most deprived local authority areas experienced cuts of $£ 228.23$ per person, while the 10 per cent least deprived areas experienced cuts of $£ 44.91$ per person (SPERI 2015). From 2015/16, the Institute of Fiscal Studies (2019), show further considerable falls in spending power of local authorities. The imperative to raise income led to sales of public assets. The need to create revenue from an asset sale was the most significant reason hindering CAT, reported in a survey of local government officers (Gilbert 2016, p. 3). Local government sold over 4000 buildings per year, over a five-year period, from 2012/13 to 2016/17 (Locality 2018a). Over 700 public football pitches have been lost since 2010 (GMB Union 2019). Since 2014/15, over 12,000 public spaces have been disposed of (Davies et al. 2019). Sales were stimulated in April 2016 when rules on how local authorities could spend income from sales of property were changed. Previously, money made from selling public assets could only be used to fund the cost of buying new ones. From April 2016, local authorities could spend the proceeds on cost-cutting measures. Thus, since 2016, almost a third of the income raised from property sales was spent on making employees redundant (Davies et al. 2019).

While there are policy differences between the countries of the UK a common denominator is reacting to reductions in public expenditure and; as several authors have argued, a dominant neoliberalism. The Scottish perspective shows a slightly different balance between austerity and ideology. Scotland has a longer history of supporting community 
land trusts to buy land under The Land Reform (Scotland) Act 2003, (Moore and McKee 2013) and transfers are enacted differently under Sect. 5 of the Community Empowerment (Scotland) Act (2015). By 2011 nearly half a million acres of the country; $2 \%$ of the landmass; was held in community ownership via 200 community groups (O'Leary et al. 2011). In 2009, the Development Trust Association, Scotland, received funding from the Scottish Government to deliver the 'Promoting Asset Transfer' programme to increase levels of awareness and interest within local authorities as a means of increasing community ownership of assets and asset transfer is central to the Scottish Government's Community Empowerment Action Plan. Scottish Government policy provided some protection for council budgets as, between 2009 and 2013, overall expenditure reduced by $11 \%$ compared with $13.5 \%$ in England (Reid 2018). In 2015, Murtagh (2015) claimed there was slightly less infrastructure support for asset transfer in Northern Ireland, compared to the rest of the UK. Moore and McKee (2013, p. 524) claimed that 'community asset ownership in Wales and Northern Ireland is less pronounced relative to developments in England and Scotland, but in recent year's policy agendas have mirrored asset transfer initiatives elsewhere in the UK'.

\section{The Experience of CAT}

\section{Local Government Motivations and Planning}

Asset transfer is not guided by policy of central government, and $59 \%$ of councils did not have an asset transfer policy in 2018 (Locality (2018a). Although few studies have been able to interview local government policy makers (e.g., Rex 2020; Reynolds 2017), so knowledge of the planning process is limited, the consensus is that the main motivation for transfer has been cost saving. Schultz's survey of local authorities noted a shift in the emphasis away from community empowerment toward cost savings (Schultz 2016). Although Archer et al's (2019) survey was of all assets in community ownership, this noted 'a marked increase in communities bringing assets into their ownership in the last decade [with] 29 per cent of current assets [coming] into community ownership in the last 10 years' (p21). A range of studies in different parts of the UK and of varying types of facility confirm that local authorities are pursuing CAT for mainly financial reasons (Findlay-King et al. 2018a; Kenyon et al 2018; Forkert 2016; Forbes et al. 2017; Foxton 2018; Penny 2019; Robinson and Sheldon 2019; Reid 2017, 2018; Rex 2020).

There are guides to CAT for local councils which advocate a strategic approach (e.g. Locality 2018b), but budget cuts have meant councils have less staff to support
CAT and few have an officer with specific responsibility for it (Gilbert 2016). As above, a minority have an asset transfer policy, and once they transfer a facility they lose strategic control of it, within planning across a council area, anyway. Forbes and Nichols found one local authority used statistics on social deprivation and visitor numbers to inform their decision as to which libraries would remain part of the core service and which would be transferred (2020, p. 5). Rex's study of three museums (2020) found factors in decisions included: comparative maintenance costs; potential to generate revenue; visitor numbers; the contribution to strategic objectives such as tourism and regeneration plans. Another factor was assumptions about the capacity of volunteers to deliver a CAT with little support. As we have noted, the potential for transferring management to a service provider, which operates at a national level, will influence if a volunteer led group is offered a CAT. Overall, the dominant factor in the decision to sell or transfer; or who to transfer to; seems to be the amount of revenue that can be raised (Gilbert 2016, p. 3). There is a tension between local government's reluctance to let go control, and enabling the flexibility and innovation, which has been identified as a potential benefit of CAT. Schultz's research $(2016$, p. 42) found $90 \%$ of local authorities used lease conditions to balance retaining control, and transferring it to the CAT by restricting 'the use of assets, above and beyond planning use restrictions'. Thus, while the main impetus for transfers is reducing expenditure, several other factors affect the transfer.

\section{The Role of Volunteers}

All of the examples of CATs reviewed involved volunteers taking major roles in governance, delivery or both. A survey of community assets in 2019 (Archer et al. 2019); which defined these as where a lease or freehold was held by a community or voluntary organisation; found that $60 \%$ of organisations had no full-time staff and $13 \%$ had one or less. Thus, these organisations must be almost entirely reliant on volunteers, although the report did not reveal their numbers. In half of them volunteers contributed 20 or more hours per week, and in 16\%; 100 h or more. A more general survey of 'community businesses', found that in the sample of 300 organisations the median number of paid staff was 4 and volunteers 20 (Diamond et al. 2018); again confirming the major role of volunteers. Archer et al.'s survey (2019) confirms community assets have a small financial turnover; $48 \%$ had an operating turnover of between $£ 10,000$ and $£ 100,000$ per year. The major role of volunteers in CATs means understanding them needs to draw on theory of community based organisations (Aiken et al. 2011), social enterprise (Teasdale 2012), civic action and volunteering (Aiken and Taylor 2019) and the relation 
between volunteer led organisations and the state (Lindsey et al. 2018). The 2019 survey of community assets reported the number of full-time employee equivalents, but not how many had been replaced in the process of transfer. This has not been quantified in any study, although the replacement of employees by volunteers has been noted, particularly in libraries (Forbes et al. 2017, Forbes and Nichols 2020; Forkert 2016; Penny 2019; Robinson and Sheldon 2019).

\section{Volunteers' Motivations}

The predominance of volunteers means it is important to understand their motivations. We have not found a survey of volunteers' motivations in CATs; however, qualitative work shows a strong initial motivation is to stop a facility closing (e.g. Forbes et al. 2017; Forkert 2016; Foxton 2018; Griffiths et al. 2014; Penny 2019). A campaigning group against closure may transform into one, which then negotiates with local government to take on a transfer of management or ownership, and if successful will then manage the facility. This means motivations will change over three phases of CATs; campaigning, transfer and management.

As noted above, the most recent survey, which included 27 case studies, did not focus on CATs. However, it concluded that; 'The desire to retain a building or community space because of its symbolic value proved to be an incredibly powerful motivator for community ownership' (Archer et al. 2019, p. 55). Motives included 'a desire to preserve (or improve) an asset deemed to be of local value' and 'to provide benefits to the community' (2019, p. 4). Academic studies have normally included far fewer case studies but analysed discourse in more depth. These have shown that an identification with a physical facility, geographical place, or local community are important motivators; although there could be permutations of all three. Examples include: Jancovich's study of a town hall and a cinema (2016); Rex's study of 3 museums (2018a); and Corble's study of 2 libraries (2019). Further, as Moore and McKee's (2013, p. 528) review concluded: 'Communities are assumed to be able to create a cohesive sense of place through asset ownership'. Therefore, the identification with a CAT might change as the CAT develops. It is important to analyse this sense of identity in more detail to understand volunteers' motivations and the viability of CATs in retaining volunteer support. For example, Forbes and Nichols (2020) interviewed representatives of ten volunteer managed libraries in one city and found they would volunteer for the library in the geographical area they lived in, but would not consider volunteering for one of the other side of the city.

Volunteers' perceptions of CATs may be the product of many influences, including: a historical tradition of community ownership (Woodin et al. 2010); a view of the ideal boundary between the state and voluntary provision (Lindsey et al. 2018), and a view of volunteering as civic action (Aiken and Taylor 2019). As in volunteers' identification with different aspects of a facility, it is possible that researchers will focus on the elements in the social construction of volunteering in CATs, which build on their own theoretical frameworks. With regard to the changing role of the state; a study of CAT libraries asked key volunteers for their political views on transfer. These varied from; 'accepting the situation as an inevitable consequence of cuts in public expenditure and focusing on the benefits; to feeling uncomfortable in acquiescing in a process, which by its success will justify further cuts' (Forbes and Nichols 2020 p. 9). This example, and those of Corble (2019) and Forkert (2016), identified a tension in that volunteers might oppose public budget cuts and facility closures; but by contributing to a 'successful' CAT feel they are legitimising the transfer to volunteer-run services.

\section{Preparing for Transfer and Support}

The most recent survey and case studies found that the community asset transfer process was highlighted as being very complex-it requires significant time and resources from both communities and local authorities, and a lack of the specialist skills required can frustrate efforts' (Archer et al. 2019, p. 30). Transfers coinciding with cuts in local government funding has reduced the capacity of local government to offer support and the capacity of local volunteer centres; who themselves rely on local government support. This is illustrated by the transfer of libraries in a large city (Forbes et al. 2017) and Thorlby's report on supporting community ownership (2011) which noted that while volunteer led organisations needed more support, the capacity of local government to provide it had diminished.

Volunteers managing transfers required skills of 'fundraising, financial planning, negotiating, accountancy, company and employment law, working with local government, and applying for grants/loans. (An) important requirement was securing the involvement of people who were able to balance these specific skills (for example in business, planning and commerce) with a focus on the needs of the local community' (Archer et al. 2019, p. 37). Transfer is most viable where social capital; volunteer time, confidence, skills and connections; is high (Forbes et al. 2017; Findlay-King et al. 2018b). Many volunteers able to offer their free time are retired, and are living in areas of high affluence/lower deprivation. Particular skills and resources are needed, thus affluent community groups are more likely to commit to action then those living in deprived areas (Lennox 2016, pp. 232-34). Similarly, the heritage sector is concerned that community groups do not represent the overall community they wish to serve (Foxton 
2018). Skerratt and Hall (2011b, p. 665) conclude we need to ensure 'community participation in development does not favour only the articulate, well-networked and vocal...'. Other areas will need on-going support, either from the public sector, or from existing umbrella organisations. Essentially, the most advantaged areas; in terms of social capital; are most likely to have the volunteers to manage a CAT. Field et al. (2015) claim BAME communities are disadvantaged, although only based on interviews in 14 community organisations. An appreciation of these inequalities of capacity led Aiken et al. (2011) to recommend that Government should take note of the obstacles that hinder disadvantaged areas, which may lack capacity and opportunities to create additional revenue from community assets. However, relative disadvantage has increased since 2011 and the councils who need to offer most support on these criteria have been the ones with budgets cut the most (SPERI 2015).

\section{The Experience Post-Transfer}

An early expert review (O'Leary et al. 2011, p. 46) found case studies and reports suggesting benefits of community management to be: generation of income from the asset; contribution towards growing and/or regenerating local economies; increased opportunities for local participation in management of local assets; building a sense of empowerment and community; and increased community pride in place. Similar benefits were identified in Aiken et al.'s (2011) survey of community organisations. Studies of CATs in leisure a few years after transfer have found the flexibility of management has allowed them to cut costs and to make the services they offer more responsive to local needs (Fenwick and Gibbon 2016; Aiken et al. 2011; Findlay-King et al. 2018b). The use of volunteers from the community as trustees and in operational roles brings the trust closer to the community to understand and respond to needs (Findlay-King et al. 2018b). A more focused study of libraries (Forbes and Nichols 2020) found that post-transfer they had greatly expanded the range of services offered to become what is commonly termed 'community hubs'.

The relatively recent history of CATs, combined with political sensitivity, makes it difficult to study reasons for success or failure. To survive CATs will require to be economically sustainable, and replace volunteers as they retire. As in the ability to manage a transfer, both these resources are unevenly distributed. Economic sustainability will rely on generating local income. The ability to do this is also uneven. This is illustrated by Power to Change's guide to cafés in community businesses which came to the obvious conclusion that (2019, p. 1): 'Where your café building is matters; and this can have a big influence on the types of customers you can attract, the price you can charge and the scale of café you can run.' The uneven ability to generate income was illustrated Forbes and Nichols (2020) comparison of libraries in one city; where this varied widely, corresponding to the social deprivation index of the catchment areas. The scope for libraries generating income depends on the adaptability of the building, the socio-demographics of the community, and the innovation of the management income generation (Forbes et al. 2017; Forbes and Nichols 2020; Corble 2019). An unknown impact on economic sustainability is the ability of local government to continue to provide a subsidy at the present rate, where this applies.

However, for volunteer managed CATs, economic viability is a means to social ends, as illustrated by a recent study of CAT libraries (Forbes and Nichols 2020). They can be described as a 'voluntary/public/private hybrid'; balancing the aims of each (Billis 2010). Archer et al. note how participants responded to questioning about the financial health of their organization in a way that indicated 'maximising surpluses was not a primary concern for many and generally 'good' (financial health) was deemed to be an operating income that covered operating expenses' (2019, p. 86). The prioritisation of non-financial objectives in community organisations was also confirmed by Aiken et al. (2011, p. 5). As in all voluntary led organisations, sustainability will depend on the continual recruitment of volunteers; the supply of which has been at a constant level since 1979 (Lindsey et al. 2018). Thus, CATs need to compete for a finite supply.

\section{Methodologies and Theoretical frameworks}

This section contrasts methodological approaches and reviews some of the theoretical frameworks applied to studying CATs. It shows how research has theorised the interplay between agency and structure inherent in sociological theory (Giddens 1971). Clearly structural forces; the impact of reduced local government budgets and the different markets for the transfer of different leisure facilities; determine the opportunities volunteers have to bid for a CAT. However, the experience of CAT is also socially constructed. This section contrasts the main approaches used in previous research; a social constructionist approach, using analysis of language, with analysis drawing on a Gramscian or neo-Marxist approach. It considers how both approaches have analysed a contested neoliberalist hegemony. Briefly, the alternative methodology of scientific realism is considered.

Methodological assumptions are most obviously stated in doctoral theses; although not as clearly as one would like. Rex's methodology, in a study of three museums used actor-network-theory. This assumes that the world is 
comprised of socially constructed entities and research has to understand 'associations and the relations between entities in networks'; thus, '...analysis becomes tracing process and associations between entities of all types' (Rex 2018a, p. 52). The exercise of power in this network of relations was used to explain; for example; the decision making process about which buildings to transfer and the development of the relationship between the asset transfer group and the local authority. This built on methodologies used in cultural geography (e.g. Murtagh and Boland 2017) which have been developed from post-modernist theorists advocating the analysis of language, for example, Latour (1996). A criticism of the postmodernist approach and Latour in particular, is that it is not possible to make definitive statements about the world because any view is socially relative (Harvey 1989). However, Rex may not share this view, and is often the case with doctorate studies; authors are encouraged to develop practical implications of their findings. Rex has done this by producing a guide for the Association of Independent Museums on managing asset transfer (Rex 2018b) and a guide on business models for heritage facilities (Rex et al. 2019).

Foxton's doctoral research (2018, p. 109) into two heritage buildings also used a constructionist and interpretivist approach, in which 'meanings behind uttered statements and actions... were quantified ... to present trends across different groups'. Observations, interviews and ethnographic participation were used, including being a paid consultant for one project. Thus, this research was partly ethnographic. Foxton had to reconcile the theoretical implications of a social constructivist position with the requirements of a Collaborative Doctoral Award with the City of York Council to make practical recommendations.

Corble's (2019, p. 4) ethnographic study of two libraries used interviews. Like Foxton, she had to reflect on her own involvement, which was over a period of 8 years in one library. In contrast to Rex her position puts greater emphasis on the interplay of structure and agency as she uses the concept of 'conjuncture' to analyse 'inherent contradictions and over determinations of structural social forces that produce transformations from one dominant political settlement to another' (2018a, b, p. 29). The concept of a 'conjunctural crises' (Hall and Massey 2010, p. 57) is used to describe how hegemonic forms of governance and economics can be challenged to offer opportunities to transform social relations. Despite their contrasting methodological positions on what can be said about 'reality' all three theses agree that 'new management arrangements ... emerge out of ... austerity politics ... borne out of an ideological ambition to reduce the size and scope of the public sector (Rex 2018a, p. 52).

Methodological positions of academic papers; although not usually explicitly stated, may be deduced through the methods used. Research reports tend to be a-theoretical but the methodological predilections of major funders of research; including The Joseph Rowntree Foundation, Power to Change and Locality; are reflected in a pragmatic blend of surveys, interviews and case studies, which complement each other.

The theoretical frameworks used also need to explain the balance of agency and structure.

A common theme of studies of CATs is that discourses are contested (e.g. Featherstone et al. 2012; Foxton 2018; Corble 2019; Penny 2019; Reid 2018). Teasdale (2012) illustrates this in the change in description of communitybased organisations from co-operatives to non-profits, using resource dependency theory and institutional theory. Within this, organisations may change the way they describe themselves to match a dominant ideology. Dey and Teasdale (2016) used a longitudinal qualitative study to show how the manager of a social enterprise used tactical mimicry to change the description of his organization in order to attract government funding.

Where the focus has been contested discourses this has frequently claimed to be around the imposition of a neoliberalist hegemony, but neo-liberalism is rarely clearly defined. This may be because it is assumed to be generally understood, however identifying the assumptions embodied in neo-liberalism allows one to see how they are imposed and contested. Neoliberalism, as developed in economic theory, embodies assumptions that include: the unregulated interaction of supply and demand is the most effective way of distributing resources; the state should take as small a role as possible; the aim of organizations acting within the market is to make a profit; it is human nature to pursue competitive self-interest; freedom to act in an economic market is a precondition for political freedom; and power is irrelevant (adapted from Rowarth 2017). Immediately it is clear how these assumptions ignore the motives of volunteers and community based organizations, which are not dominated by self-interest. These dominant assumptions could explain why government policy is to regard community organizations as a 'player in the market' (Lindsey et al. 2018); as 'non-profits' (Teasdale 2012); the attempt to divorce civic action from volunteering (Aiken and Taylor 2019); and why government supported organisations, such as Power to Change, focus on supporting 'community business'. However, it is still necessary to explain the dominance of neoliberalism.

The concept of hegemony explains how the assumptions of neo-liberalism can dominate, however 'hegemony' is also rarely explained; in particular the way it balances agency and structure. Hegemony became important in cultural studies in the 1980s. Developed from the insights of Gramsci and Raymond Williams it was understood as a whole body of practices and expectations, which shape 
perceptions of ourselves and our world (Eldridge and Eldridge 2005). Assumptions are embodied in social constructs, but constructs are contested; the outcome of which reflects the distribution of power. A classic exposition of this process, although pre-dating cultural studies, was Thompson's (1967) analysis of the development of the concept of time and work discipline, as industrial capitalism replaced an agrarian economy. This is relevant to leisure because the use of hegemony in cultural studies was used to analyse the development of 'leisure' (Clarke and Critcher 1985), as juxtaposed to work in time and place and its association with consumption. A more recent example of the development of these theoretical foundations is the analysis of sport, such as Giulianotti (2015).

Studies have applied this theoretical framework to study CATs. Corble's study of libraries was described above. Reynolds's (2016) used post-structural discourse analysis to describe community development between 2010 and 2015 in which analysis of interviews and documents revealed a dominant discourse labelled, 'enterprise'. This included a negative conceptualisation of community development and an increasing reliance on volunteers to keep existing community development processes running. Reynolds concludes that the only discourse with a potential to challenge this at a national level is a 'social justice/ democracy discourse'. This 'articulates (community development) as a radical and active democratic process that operates within civil society movements independent of the state and is committed to egalitarian and redistributive equality and social justice' (Reynolds: 275). This illustrates how, in contrast to the social relativism of a postmodernist position, Reynolds (p.1) advocates action: 'To protect community development from future attacks, this thesis proposes ... to unearth these problematic roots to then cultivate a community development free of such underpinnings'. Another variety of critical discourse theory; closer to Gramsci's use of hegemony; was used to understand the role of neoliberal discourse in the contested closure of a community swimming pool in Australia. This also concluded by advocating action: '... both the physical swimming pool and the ideas of social justice and public goods that have underpinned its retention remain to be defended ...' (Griffiths et al. 2014, p. 292). More generally, challenging hegemony allowed Levitas to move from criticising the Big Society rhetoric to suggesting 'the economic and social conditions under which these ideas would cease to be repressive moralising claptrap' (Levitas 2012 p. 336). The point is not necessarily to agree with the actions advocated by Reynolds, Griffiths or Levitas, but rather to note that they think their methodological position allows them to recommend changes.

Interestingly, none of the work reviewed has built on economic theory to analyse CATs, despite a consensus that economic forces have stimulated CAT and attaining economic sustainability being a common challenge. An economic framework is more prominent in analysis in the United States; where the term 'non-profit' is commonly used to describe community based organisations (for example, Steinberg 2006). Some would consider its use part of a neo-liberalist hegemony!

A possible alternative methodology is offered by scientific realism. This offers another approach to examining the interplay of agency and structure and understanding an external reality. Briefly, scientific realism's ontological position is that there is an external reality but scientist's conceptualization is simply one way of knowing that reality. Science is the systematic attempt to express in thought the structures and ways of acting of things that exist and act independently of thought (Bhaskar 1975). A balance of agency and structure is achieved by understanding causality as 'generative'; which means it is a combination of human agency and its reaction to new opportunities and resources (Pawson and Tilley 1997). Studying a CAT would still need to understand volunteers' social construction of their experience. This might include: their conception of volunteering and the balance between the state and the voluntary sector; how the CAT offered a new range of opportunities and challenges; the resources and attitudes the volunteers brought with them; and how these changed as the CAT developed. These would be understood in the circumstances; the 'context' in scientific realism's terms; which permitted action to lead to particular outcomes. To our knowledge, scientific realism has not been applied to researching CATs yet.

It is unusual for research to use an interdisciplinary approach. It has drawn on theory from third sector research (Aiken and Taylor 2019), cultural geography (Foxton 2018; Murtagh and Boland 2017; Rex 2018a) leisure studies (Findlay-King et al. 2018a, b, Reid 2018) and local government studies (Skerratt and Hall 2011a, b). Research within just one academic body of knowledge leads to a development of understanding limited by this starting point, but an interdisciplinary approach might be more helpful for practitioners. Inevitably, $\mathrm{PhD}$ work has started from and finished with a narrow theoretical base, as its main aim is to add to theory.

\section{Research Practicalities}

As well as research being limited by its theoretical starting point other constraints are the lack of a sampling frame for CATs, the pragmatic selection of case studies, limitations of data sources and difficulty of access to politically sensitive situations. 
Survey work has been possible where the research has had external funding [e.g. Archer et al. 2019) but the heterogeneity of CATs makes it difficult to generate a representative sampling frame. Local authorities do not normally have a named officer to manage CAT, so surveys directed at them have a low response rate, as it is not clear whom to send them to (e.g. Gilbert 2016; Schultz 2016). Gilbert's survey of local authorities (2016) had a $14 \%$ response rate from 353 local authorities in England, so only 49 responses. Thus surveys of community assets (Aiken et al. 2011; Archer et al. 2019); have tried to generate their own sampling frames, which have not been confined to CATs. The 2019 survey used a sampling frame from, 'membership bodies, funders, national data sets, and a register of community assets developed for this study' (Archer et al. 2019, p. 3). A questionnaire was sent to 3000 assets thought to be in community ownership; from 551 responses, 365 were validated as assets in community ownership. The sample was self-selected and the invalid responses illustrate the difficulties of finding a definition, which unambiguously describes community assets. The sampling frame and response rate qualify the results; some of which have been cited above. The heterogeneity of organisations in the 2019 sample means the quantitative results are making unrealistic comparisons, for example, between sports centres and libraries.

A typology of CATs to allow research to focus on one type would overcome the problems of existing surveys trying to aggregate results from disparate organisations. The theoretical rationale for a typology would reflect the research question, and be justified by the review above. For example: if research was focussed on economic sustainability; this will vary by the ability to raise income; which in turn reflects the willingness of the public to pay for services, the flexibility of the building space, the imagination of the managers, and the level of income in the local community. To research sustainability, the most valuable results will be from CATs, which have been running for the longest (see, Findlay-King et al. 2018b). Another starting point would be to cluster a sample of local authorities; by level of social deprivation, political affiliation and the size of budget cut; as the SPERI analysis (2015) showed these to vary, but were linked. One could then develop a cooperative approach to research in selected authorities, which illustrated the range of transferred facilities. These typologies could still be placed in the broader context provided by this review.

Much of the academic work has been conducted through case studies. The heterogeneity of CATs makes a case study approach valuable; such as the 27 case studies in the latest Power to Change report (Archer et al. 2019) and the numerous examples in this review. These give detail about a small number of cases, but the selection of cases is often informed as much by pragmatic decisions on locality and access as on theoretical justification, which would make it easier to develop generalizable theory from them. Case studies have used a limited range of information, although all have used interviews. It has been rare to juxtapose the views of volunteers leading transfers, local government employees, local politicians and the public using the facility. Where some of these perspectives have been compared, they can show how they interact (e.g. Rex 2018a; Rex et al. 2019; Reynolds 2017).

Secondary data sources may give useful insights but these depend on its validity. For example, the longitudinal analysis of CIPFA records of public library visits and issues; and the identification of volunteer managed libraries within this; is limited by the decreasing number of libraries and local authorities contributing to the data set (O'Bryan 2018) and the under-representation of community libraries. Freedom of Information requests have produced useful quantitative information. For example; showing a third of income from property sales since 2016 was spent on making people redundant (Davies et al. 2019); how many assets had been sold (Locality 2018a) and specifically, the sale of public football pitches (GMB Union 2019). Data, which has not been exploited, is returns to the charity commission, required annually by all charitable trusts, which includes financial accounts.

One reason for the limited range of information sources is the political sensitivity of CATs. There are few documented cases of unsuccessful transfer (e.g. Fischer and McKee 2017). The authors of this paper have found access to these blocked by local government employees or volunteers themselves. The question of how much public funds have been saved by CATs has been ignored, probably because of the sensitivity of replacing paid employees with volunteers. The word 'asset' could obscure the aim of local government to reduce budgets by transferring liability for running and capital costs; as in the example of leisure centres in Newcastle (Newcastle Chronicle 2016). The danger of a transfer of responsibility being a liability for CATs has been anticipated (O'Leary et al. 2011) and explored (Forbes and Nichols 2020) but not by government sponsored research.

Gaining access to CATs requires the co-operation of research brokers. There may be difficulty reconciling the demands of these brokers, and those of universities or research funders. For example, Foxton (2018) sensitively describes the difficulties arising from holding a Collaborative Doctoral Award with the City of York Council in positioning her between the interests of the Council and the CAT volunteers. She elaborates on the difficulties of reconciling these with the demands of university research (Foxton 2018, 112/3). Scientific realism (Pawson and Tilley 1997) recognises that research is co-production of 
knowledge; for example, in the conduct of interviews (p165). It is especially important to be sensitive to the motivations and need of volunteers managing and delivering CATs to maintain their goodwill and cooperation. They need to be assured that research will benefit them. This requires academics to build this into the design of research, and ensure this is what it delivers. This is also important when working with local government officers. In effect, the idea of co-production of services (Bovaird and Loeffler 2012) could be adapted to co-production of research.

This section has illustrated ways in which designing research into CATs has to carefully maximise the opportunities and minimise the limitations. The next section considers specific research questions.

\section{Research Questions}

Having reviewed what is known about CATs in leisure we are able to conclude with a brief set of questions about what is not known. This section is limited to the questions themselves, rather than developing proposals in detail. It is for others to do this, building on the methodologies, theoretical frameworks and research practicalities reviewed above. We build on the suggestions offered by Moore and McKee (2013) and Reid (2018). For brevity, we have clustered questions together and left it for the reader to make the links to the extensive review material above. They are not rooted in any particular academic discipline but illustrate an interdisciplinary approach.

Measuring CATs is difficult because of the lack of sampling frames, poor response rates, self-selecting in response to a prompt such as those describing a 'community business', and the heterogeneity of CATs. The most reliable on-going source is probably Public Libraries News, which only covers libraries. This suggests that attempts at quantification could focus on specific types of CATs. Generating a typology could be by facility function; for example; sports facilities, libraries, museums or heritage buildings. This is justified by the different market positions of these CATs and interest groups with which researchers could work (for example, the Association of Independent Museums). Other possible typologies could be by: income level and staff expenditure; number of assets managed; objectives and organizational values; if responsibility for maintenance has been transferred, or just management; and if a contracted out service agreement is in place. These distinctions might justify case study selection. The experiences of CAT will also vary between the different jurisdictions of the UK. There is a balance to be struck between clustering the heterogeneous CATs into typologies for ease of research, and drawing out common understandings. Hopefully this review can contribute towards this.

The number of volunteers and roles they take are critical to CATS yet we know little about them. Studies of the motivations of the volunteers, their demographics and the pools of social capital they bring, need to differentiate between phases of transfer. Much of the detailed case study work has explored the social construction of the volunteers' experiences. Their motivations will reflect identifications with place, facility, 'local' community, and perceptions of the political justification or otherwise of CAT. How will these change as volunteers' involvement changes from preventing a public facility from closing, to making the transfer viable, to maintaining a different type of facility? They will also change with involvement in CATs over time. Is there potential for volunteers' understanding of CATs to move from saving their own particular facility to challenging a neoliberalist hegemony; which has underpinned cuts in the welfare state; and being led by a vision of how societies' needs can be better met? Where would this vision of 'something better' come from?

We know nothing of public perceptions of CATs. Do the local service users realise the facility is now managed and delivered by volunteers? Is their perception changed from that of a public facility paid for by taxes to which everybody is entitled to use; to a facility; like a community sports club; which is reliant on mutual aid? How does this affect their propensity to volunteer?

How does local government make decisions to transfer, sell or close facilities? Unsurprisingly, it has been difficult to gain insights into this, beyond the imperative to cut costs. We know little about the social construction of CAT amongst local government officers and politicians, the interactions between them, and with the volunteers negotiating transfer. What are the conflicts and synergies of aims between these stakeholders? Can we learn from this what contributes to a successful transfer; and what the stakeholders regard as 'success'?

What are the gains and losses from CATs and who has experienced them? How many employees have lost their jobs? How much has been saved from public budgets? Has the transfer to management by local volunteers made the service more responsive to local needs or do the volunteers inevitably tend to manage to meet their own interests rather than those of the broad community? What are the qualitative benefits to the local community of a more responsive service? What are the benefits to the volunteers from the experience of volunteering, but also the burdens and challenges? Do they experience 'burn out' from the demands of the roles and does this make it even more difficult to recruit replacements? What is good practice in volunteer management for recruitment, development and 
retention; given in most cases volunteer 'managers' are volunteers themselves?

As the viability of transfer relies on a pool of volunteer time and capital, which is unevenly distributed, will this mean that facilities stay open where this is high, and close where it is low? Will the ability to recruit new volunteers to replace the existing ones also reflect social divisions? In the longer term, as local government subsidy is reduced further and CATs have to rely more on generating their own income, will those in more advantaged areas be able to attain long term financial viability, while those in disadvantaged areas will not? Overall, does transfer mean services for all as a welfare right will be replaced by services concentrated in the areas of social advantage; where volunteers have the time, skills and capacity; and where sufficient income can be raised locally to make them economically viable?

Given the reduced capacity of the public sector to support transfers with advice or subsidy, how can government resources be used most effectively to maximise the benefits and minimise the losses from CAT? What support would be most valuable for CATs?

\section{Conclusions-Broader Research Questions}

The questions above present a research agenda that could be tackled collectively; by type of facility, or by issue. In summary CAT is transforming leisure and cultural services as their delivery is transferred from the public to the voluntary sector. The questions above are within a debate about where the boundary should lie between statutory responsibility and voluntary initiative (Lindsey et al. 2018). This is particularly well illustrated by the focus on leisure services because of their non-statutory provision. This focus also illustrates the need to consider the interaction of agency and structure. The same structural forces have influenced cuts in public subsidy for sports centres, libraries, museums and heritage buildings; however, the 'market' for transferring management of these is different. This determines if volunteers will be given the opportunity to take on a CAT and the extent to which they can make it financially viable.

The interplay of agency and structure is also apparent in the construction, and challenge, of a neoliberalist hegemony; reflected in the contested discourse of community organisations and volunteering. For example, to what extent is a community organisation obliged to define itself as a 'community business' to obtain funds? Does this hegemonic discourse preclude CATs being part of an alternative means of providing society's needs, and indeed, defining what those needs are? Can it to be challenged?
These questions are relevant to other countries experiencing the same structural forces. Stepping back, the major stimulus for CATs has been austerity politics; which was a response to the economic crises of 2008. If this represents the start of a collapse in capitalism, what is the ideal balance of voluntary, public and private provision in meeting the needs of a post-capitalist system (Blühdorn 2017; Mason 2015)? As we write, the world is struggling with adapting to a Covid pandemic. The outcome is unknown, but will a third sector, with volunteering having a very local community focus, become a more important way of meeting society's needs as public budgets are cut further? CATs could be in the vanguard of this.

Acknowledgements The authors would like to thank those who participated in the stakeholder discussion. We acknowledge the contributions of Dr Bethany Rex and Dr Katrina Foxton to the development of this paper. We also extend our thanks to the two anonymous reviewers for their comments, and to the editors. The views in the paper are entirely our own. (1) The review group helping identify research issues comprised members of the following organisations. Power to Change is a Charitable Trust operating in England, created in 2015 with a $£ 150$ million endowment from the Big Lottery Fund. The trust is solely concerned with supporting Community Businesses in England over a ten-year period, after which it will cease operating. Its vision is 'to create better places through community business'. https://www.powertochange.org.uk/about-us/ Community Leisure UK is a members' association that specialises in charitable trusts delivering public leisure and culture services across the UK. https://communityleisureuk.org/ The Community Managed Libraries Peer Network aims to help community libraries share good practice, and is funded by Power to Change. https://communitylibrariesnet work.wordpress.com/about/ Arts Council England is a non-departmental public body of the government Department for Digital, Culture, Media and Sport. Locality are a national membership network of over 500 local community organisations. Some of their research reports have been funded by Power to Change. https://local ity.org.uk/about/.

Open Access This article is licensed under a Creative Commons Attribution 4.0 International License, which permits use, sharing, adaptation, distribution and reproduction in any medium or format, as long as you give appropriate credit to the original author(s) and the source, provide a link to the Creative Commons licence, and indicate if changes were made. The images or other third party material in this article are included in the article's Creative Commons licence, unless indicated otherwise in a credit line to the material. If material is not included in the article's Creative Commons licence and your intended use is not permitted by statutory regulation or exceeds the permitted use, you will need to obtain permission directly from the copyright holder. To view a copy of this licence, visit http://creativecommons. org/licenses/by/4.0/.

Funding The review group meeting in February 2019 was supported by a grant from the University of Sheffield.

\section{References}

Aiken, M., Carins, B., Taylor, M., \& Moran, R. (2011). Community organisations controlling assets: a better understanding. 
Available: https://www.jrf.org.uk/report/community organisations-controlling-assets-better-understanding. York: Joseph Rowntree Foundation. Retrieved April 2020.

Aiken, M., \& Taylor, M. (2019). Civic action and volunteering: the changing space for popular engagement in England. VOLUNTAS: International Journal of Voluntary and Nonprofit Organizations, 30(1), 15-28.

Archer, T., Batty, E., Harris, C., Parks, S., Wilson, I., Aiken, M. Buckley, E., Moran, R., \& Terry, V. (2019). Power to Change Research Institute Report No. 21. Our assets, our future: the economics, outcomes and sustainability of assets in community ownership. London: Power to Change.

Forbes, D., Findlay-King, L., Macfadyen, G., \& Nichols, G. (2017). Lessons to be learnt-One size does not fit all. From public to volunteer library provision in the UK. Voluntary Sector Review, 8(3), 343-353.

Findlay-King, L., Nichols, G., Forbes, D., \& Macfadyen, G. (2018a). Localism and the Big Society: the asset transfer of leisure centres and libraries-fighting closures or empowering communities? Leisure Studies, 37, 158-170.

Findlay-King, L., Nichols, G., Forbes, D., \& Macfadyen, G. (2018b). Watching the pennies and the people - how volunteer led sport facilities have transformed services for local communities. Managing Sport and Leisure, 23(4-6), 277-292.

Forbes, D. \& Nichols, G. (2020) The community asset transfer of libraries: considerations in community managed libraries taking a lease. Available https://www.sheffield.ac.uk/polopoly_fs/1. 878412!/file/Library-report-final-2020.pdf. Accessed Apr 2020.

Bhaskar, R. (1975). A realist theory of science. Leeds: Leeds Books.

Billis, D. (Ed.). (2010). Hybrid organizations and the third sector: Challenges for practice, theory and policy. Basingstoke: Palgrave Macmillan.

Blühdorn, I. (2017). Post-capitalism, post-growth, post- consumerism? Eco-political hopes beyond sustainability, Global Discourse, 7(1), 42-61.

Bovaird, T., \& Loeffler, E. (2012). From engagement to coproduction: the contribution of users and communities to outcomes and public value. VOLUNTAS: International Journal of Voluntary and Nonprofit Organizations, 23, 1119-1138.

Clarke, J., \& Critcher, C. (1985). The Devil makes work: Leisure in capitalist Britain (Crisis points). Basingstoke: Macmillan Education.

Corble, A. (2019). The Death and Life of English Public Libraries: Infrastructural Practice and value in a time of crisis. $\mathrm{PhD}$ thesis, University of London: Goldsmiths. http://research.gold.ac.uk/ 26145/1/SOC_thesis_CorbleA_2019.pdf. Retrieved April 2020.

Davies, G., Boutaud, C., Sheffield, H., \& Youle, E. (2019). Revealed: The thousands of public spaces lost to the council funding crisis. The Bureau of Investigative Journalism 4 March [Online] Available: https://www.thebureauinvestigates.com/stories/201903-04/sold-from-under-you. Retrieved March 2019.

Diamond, A, Vorley, T, Higton J, Archer, R, Steer, R., \& Mulla, I. (2018). The Community business market in 2018. Power to Change [Online] Available https://www.powertochange.org.uk/ wp-content/uploads/2018/12/Report-19-Community-BusinessMarket-2018-FINAL-DIGITAL.pdf. Retrieved June 2019.

Eldridge, E., \& Eldridge, J. (2005). Raymond Williams: Making connections. Abingdon: Routledge.

Featherstone, D., Ince, A., Mackinnon, D., Strauss, K., \& Cumbers, A. (2012). Progressive localism and the construction of political alternatives. Transactions of the Institute of British Geographers, $37(2), 177-182$

Fenwick, J., \& Gibbon, J. (2016). Localism and the third sector: New relationships of public service. Public Policy and Administration, 31, 221-240.
Field, Y., Murray, K., \& Chilangwa-Farmer, D. (2015). A Place to Call Home: Community Asset Ownership in the African Diaspora Community. Locality. https://static1.squarespace.com/sta tic/58f9e592440243412051314a/t/5dcd70eb44fbbd622c2e4b97/ 1573744880563/A+Place+to+Call+Home+report+final+ver sion.pdf. Retrieved April 2020.

Fischer, A., \& McKee, A. (2017). A question of capacities? Community resilience and empowerment between assets, abilities and relationships. Journal of Rural Studies, 54, 187-197.

Forkert, K. (2016). Austere creativity and volunteer-run public services: The Case of Lewisham's Libraries. New Formations, $87,11-28$.

Foxton, K. (2018). Within the Walls Project: Comparing Heritage Values as Action within Council \& Community Asset Transfer Practices, York, UK 2014-2016. Unpublished PhD thesis, University of York. (Currently under embargo).

Giddens, A. (1971). Capitalism and modern social theory: An analysis of the writings of Marx. Durkheim and Max Weber: Cambridge University Press.

Gilbert, A. (2016). Power to Change Research Interest Report No. 3 A common interest: the role of asset transfer in developing the community business market. [Online] https://www.powerto change.org.uk/wp-content/uploads/2017/05/2016-A-commoninterest-The-role-of-asset-transfer-in-developing-the-commu nity-business-market.pdf. Retrieved: February 2019.

Giulianotti, R. (2015). Sport: A critical sociology. New York: Wiley.

GMB Union (2019). More than 700 council football pitches lost as austerity trashes next generation on football pitches lost. https:// www.gmb.org.uk/news/more-700-council-football-pitches-lostausterity-trashes-next-generation. Retrieved June 2019.

Griffiths, T., Connor, T., Robertson, B., \& Phelan, L. (2014). Is Mayfield Pool saved yet? Community assets and their contingent, discursive foundations. Community Development Journal, 49(2), 280-294.

Hall, S., \& Massey, D. (2010). Interpreting the crisis. Soundings: A Journal of Politics and Culture, 44, 57-71.

Harvey, D. (1989). The condition of postmodernity. Oxford: Blackwell.

Institute of Fiscal Studies (2019). Real terms change in council's core spending power, 2015-16 to 2019-20. [Online] https://www.ifs. org.uk/publications/13771. Retrieved May 2019.

Kenyon, J. A., Mason, C., \& Rookwood, J. (2018). Emerging third sector sports organisations and navigating uncertainty in an' era of austerity': a single ethnographic case study from Liverpool. International Journal of Sport Policy and Politics, 10(1), 25-42.

Larkin, J. (2018). Mapping Museums: Preliminary results on UK museum closure, 1960-2017. [Online] http://blogs.bbk.ac.uk/ mapping-museums/2018/02/23/museum-closure-pre-findings/. Retrieved August 2019.

Latour, B. (1996). On interobjectivity. Mind, Culture, and Activity, $3(4), 228-245$.

Lennox, R. (2016). Heritage and Politics in the Public Value Era An analysis of the historic environment sector, the public, and the state in England since 1997. Unpublished: University of York. $\mathrm{PhD}$.

Levitas, R. (2012). The Just's Umbrella: Austerity and the Big Society in Coalition policy and beyond. Critical Social Policy, 32(3), 320-342.

Lindsey, R., Mohan, J., Bulloch, S., \& Metcalfe, E. (2018). Continuity and change in voluntary action: Patterns, trends and understandings. Bristol: Policy Press.

Livsey, G. (2015). Leisure facility management operators. (Personal communication, April 2015).

Locality (2018a). The great British sell off: how we are losing our vital publicly owned buildings and spaces. Forever. [Online] 
https://locality.org.uk/wp-content/uploads/2018/06/The-GreatBritish-Sell-Off-FINAL.pdf. Retrieved March 2019.

Locality. (2018b). Building powerful communities through community asset transfer: a guide for councillors. [Online] https://locality. org.uk/wp-content/uploads/2018/05/Understanding-CommunityAsset-Transfer-Guide-for-Councillors.pdf. Retrieved March 2019.

Mason, P. (2015). Postcapitalism, a guide to our future. New York: Penguin Random House.

Mintel (2018). Leisure Centres and Swimming Pools - UK September 2018. London: Mintel Oxygen. [Online] http:// academic.mintel.com/display/859457/. Retrieved July 2018.

Moore, T., \& McKee, K. (2013). The ownership of assets by placebased community organizations: Political rationales, geographies of social impact and future research agendas. Social Policy and Society, 13(4), 521-533.

Murtagh, B. (2015). Community asset transfer in Northern Ireland. Policy \& Politics, 43(2), 221-237.

Murtagh, B., \& Boland, P. (2017). Community asset transfer and strategies of local accumulation. Social and Cultural Geography. https://doi.org/10.1080/14649365.2017.1347270.

Newcastle Chronicle (2016). Newcastle leisure centres change hands as part of $£ 14 \mathrm{~m}$ city council cost-cutting drive. [Online] https:// www.chroniclelive.co.uk/news/north-east-news/newcastle-lei sure-centres-change-hands-10680723. Retrieved January 2016.

O'Bryan, J. (2018). Analysing data: CIPFA statistics and the future of England's libraries. [Online] https://www.gov.uk/government/ publications/analysing-data-cipfa-statistics-and-the-future-ofenglands-libraries. Retrieved March 2019.

O’Leary, T., Burkett, I., \& Braithwaite, K. (2011). Appreciating Assets. Carnegie UK Trust. https://www.carnegieuktrust.org.uk/ publications/appreciating-assets/. Retrieved April 2020.

Pawson, R., \& Tilley, N. (1997). Realistic evaluation. London: Sage.

Penny, J. (2019) 'Defend the Ten': everyday dissensus against the slow spoiling of Lambeth's libraries. Society and Space O(0), $1-19$.

Power to Change (2019). The community business success guide to cafes [Online] https://www.powertochange.org.uk/wp-content/ uploads/2018/06/PTC_Cafes_A5_AW-1.pdf. Retrieved September 2019.

Public Libraries News (2019a). [Online] http://www.publiclibraries news.com/about-public-libraries-news. Retrieved April 2019.

Quirk, B. (2007). Making assets work: the Quirk Review of community management and ownership of public assets. London: The Stationery Office.

Ramchandani, G., Shibli, S., \& Kung, S. P. (2018). The performance of local authority sports facilities in England during a period of recession and austerity. International Journal of Sport Policy and Politics, 10(1), 95-111.

Reid, G. (2017). A fairytale narrative for community sport? Exploring the politics of sport social enterprise. International Journal of Sport Policy and Politics, 9(4), 597-611.

Reid, G. (2018). Managing budget cuts in Edinburgh's sport and recreation services: progressive localism in a resilient local authority? International Journal of Sport Policy and Politics, 10(1), 113-129.

Rex, B. (2018a). Local Authority Museums After the Cuts: A Study of Other-than-Public Forms of Management, Unpublished $\mathrm{PhD}$ thesis, Newcastle University. https://theses.ncl.ac.uk/jspui/han dle/10443/4118. Retrieved April 2019.

Rex, B. (2018b). "Successfully taking over your local museum: a guide to community asset transfer of museums." AIM Success Guides https://www.aim-museums.co.uk/wp-content/uploads/ 2018/09/V-5-Successfully-Taking-Over-Your-Local-Museum2018-6.pdf. Retrieved April 2019.
Rex, B. (2020). Which museums to fund? Examining local government decision-making in austerity. Local Government Studies, 46(2), 186-205.

Rex, B., Kaszynska, P., \& Kimbell, L. (2019). Business models for arts and cultural organizations: Research findings from Creative Lenses. Project Report. Trans Europe Halles, Lund, Sweden. [Online] http://ualresearchonline.arts.ac.uk/14392/1/CreativeLenses-Research-Findings.pdf. Retrieved July 2019.

Reynolds, A. (2017) Community Development and the Coalition Government (2010-2015): discourse, hegemony and 'othering'. Doctoral thesis, Northumbria University. http://nrl.northumbria. ac.uk/35012/. Retrieved April 2020.

Robinson, K., \& Sheldon, R. (2019). Witnessing loss in the everyday: Community buildings in austerity Britain. The Sociological Review, 67(1), 111-125.

Rowarth, K. (2017). Doughnut Economics: Seven ways to think like a 21st century economist. London: Random House.

Schultz, A (2016). Community Asset Transfer: A review of progress and practice in post- recession England [Masters Dissertation University of Salford] [Online] https://drive.google.com/file/d/ 0B5KtZmLy2hN-cTBtOExEZ3hBbmM/view. Retrieved December 2016.

Scott, N., \& Probert, Y. (2018). Village halls, rural community hubs and buildings:The size, scale, scope and potential of these community business. [Online] https://www.powertochange.org. uk/wp-content/uploads/2018/08/Villages-open-call-report-1.pdf. Retrieved September 2019.

Sellick, J. (2014). The rural Big Society and (changing) public service delivery: A case study of Jubilee Park. Local Economy, 29(1-2), 163-169.

Sheffield Political Economy Research Institute. (2015). SPERI British Political Economy Brief No. 6 Local authority spending cuts and the 2014 English local elections. [Online] http://speri.dept.shef. ac.uk/wp-content/uploads/2018/11/Brief6-local-authority-spend ing-cuts.pdf. Retrieved December 2016.

Skerratt, S., \& Hall, C. (2011a). Community ownership of physical assets: Challenges, complexities and implications. Local Economy, 26(3), 170-181.

Skerratt, S., \& Hall, C. (2011b). Management of community-owned facilities post-acquisition: Brokerage for shared learning. Local Economy, 26(8), 663-678.

Steinberg, R. (2006). Economic theories of non-profit organisations. In W. W. Powell \& R. Steinberg (Eds.), The non-profit sector: a research handbook (117-139). London: Yale University Press.

Teasdale, S. (2012). What's in a name? Making sense of social enterprise discourses. Public Policy and Administration, 27(2), 99-119. https://journals.sagepub.com/doi/pdf/10.1177/ 0952076711401466

Thompson, E. (1967). Time, work-discipline, and industrial capitalism. Past and Present, 38(1), 56-97.

Thorlby, T. (2011). Finance and business models for supporting community asset ownership and control. Joseph Rowntree Foundation. [Online] https://www.jrf.org.uk/sites/default/files/ jrf/migrated/files/community-assets-business-models.pdf. Retrieved December 2016.

Veal, A. J. (2010). Leisure, sport and tourism, politics, policy and planning. Wallingford: CABI.

Woodin, T., Crook, D., \& Carpentier, V. (2010). Community and mutual ownership: an historical review. New York: Joseph Rowntree Foundation.

Publisher's Note Springer Nature remains neutral with regard to jurisdictional claims in published maps and institutional affiliations. 